\title{
BRief communication Personal and Social Performance (PSP) scale for patients with schizophrenia: translation to Portuguese, cross-cultural adaptation and interrater reliability
}

\author{
A escala de Performance Social e Pessoal (PSP) para pacientes \\ com esquizofrenia: tradução para o português, adaptação \\ transcultural e confiabilidade entre avaliadores \\ Anny Karinna Pires Mendes Menezes', Gamaliel Macedo¹, Paulo Mattos², Antonio Reis de Sá Júnior?', \\ Mario Rodrigues Louzã
}

\begin{abstract}
Introduction: Schizophrenia is a chronic mental disorder associated with impairment in social functioning. The most widely used scale to measure social functioning is the GAF (Global Assessment of Functioning), but it has the disadvantage of measuring at the same time symptoms and functioning, as described in its anchors. Objectives: Translation and cultural adaptation of the PSP, proposing a final version in Portuguese for use in Brazil. Methods: We performed five steps: 1) translation; 2) back translation; 3) formal assessment of semantic equivalence; 4) debriefing; 5) analysis by experts. Interrater reliability (Intraclass correlation, ICC) between two raters was also measured. Results: The final version was applied by two independent investigators in 18 adults with schizophrenia (DSM-IV-TR). The interrater reliability (ICC) was $0.812(p<0.001)$. Conclusion: The translation and adaptation of the PSP had an adequate level of semantic equivalence between the Portuguese version and the original

English version. There were no difficulties related to understanding the content expressed in the translated texts and terms. Its application was easy and it showed a good interrater reliability. The PSP is a valid instrument for the measurement of personal and social functioning in schizophrenia.
\end{abstract}

\section{Keywords}

Schizophrenia, PSP, social functioning, Personal and Social Performance scale.

\section{RESUMO}

Introdução: A esquizofrenia é um transtorno mental crônico associado a prejuízos no funcionamento social. A escala mais utilizada para medir o funcionamento social é a GAF (Global Assessment of Functioning), mas ela tem a desvantagem de medir ao mesmo tempo sintomas e funcionamento, conforme descrito em suas âncoras de pontuação. Objetivos: Tradução e adaptação cultural da escala de Performance Social e Pessoal (PSP) para o português e avaliação da confiabilidade entre avaliadores. Métodos: Foram seguidas cinco etapas: 1) tradução; 2) retrotradução; 3) avaliação formal da equivalência semântica; 4) debriefing; 5) análise por

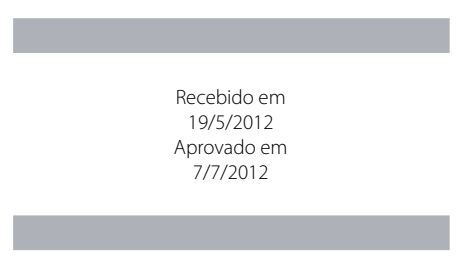

1 Universidade de São Paulo, Faculdade de Medicina, Hospital das Clínicas, Instituto de Psiquiatria (IPq-HCFMUSP), Programa de Esquizofrenia (Projesq).

2 Universidade Federal do Rio de Janeiro (UFRJ), Instituto de Psiquiatria.

3 Universidade de Würzburg, Alemanha. IPq-HCFMUSP, Projesq.

Address for correspondence: Mario Rodrigues Louzã

Instituto de Psiquiatria do Hospital das Clínicas da Faculdade de Medicina da Universidade de São Paulo (HCFMUSP)

Rua Dr. Ovídio Pires de Campos, 785 - 05403-010 - São Paulo, SP, Brazil

Telephone: (+55 11) 2661-6971

Telefax: (+55 11) 2661-7656

E-mail:mrlouza@terra.com.br 


\section{Palavras-chave}

Esquizofrenia, funcionamento social, escala de Performance Social e Pessoal. especialistas. A confiabilidade entre avaliadores (Correlação Intraclasse, ICC) também foi medida. Resultados: A versão final da PSP foi aplicada por dois investigadores independentes em 17 adultos com esquizofrenia (DSM-IV-TR). A confiabilidade entre avaliadores (ICC) foi de 0.812 ( $p$ < 0.001). Conclusão: A tradução e a adaptação da PSP mostraram um nível adequado de equivalência semântica entre a versão em português e a versão original em inglês. Não houve dificuldade na compreensão do conteúdo expresso nos textos e termos traduzidos. Sua aplicação foi simples e mostrou boa confiabilidade entre avaliadores. A PSP é um instrumento válido para a mensuração do funcionamento pessoal e social na esquizofrenia.

\section{INTRODUCTION}

Schizophrenia is a severe mental disorder usually associated with impairment of social functioning. Such losses vary among individuals and throughout the course of illness. The assessment of social functioning is therefore essential to understand the social impact of the disorder and to measure the influence of pharmacological and/or psychosocial interventions in the improvement of social performance, either as part of research procedures or routine clinical practice?.

The scale that is most widely used to measure global functioning is the GAF (Global Assessment of Functioning), which is integrated with the DSM multiaxial diagnostic system (Axis V). Nevertheless, it has the disadvantage of measuring at the same time symptoms and functioning, as described in its anchors ${ }^{2}$.

The Personal and Social Performance (PSP) scale was developed as a tool to evaluate social and personal functioning in a comparable way as the GAF, but it has two main advantages: it measures four areas of functioning and its anchors only take into consideration the functioning of the individual, independently of symptomatology. The PSP considers four areas of social and individual performance (socially useful activities, including work and study; personal and social relationships; self-care; disturbing and aggressive behaviors). For filling it, the clinician must assign an initial six-degree of severity to each area (in English: absent, mild, manifest, marked, severe or very severe). Then, in a table with levels of score set the correspondent decimal (e.g., 21-30), according to the observed performance and, within the decimal range, the assigned unit to determine the final score (e.g. within the range 21-30, the performance corresponds to the score 24). The final result is a single measurement from zero to $100 \%$ of functioning 2 .

Studies conducted to assess the reliability, validity and ability to detect clinical changes compared the PSP with the Clinical Global Impression - Severity (CGI), the Positive and Negative Syndrome Scale (PANSS) or the Quality of Life Scale (QLS) and showed that it is an adequate measure of social functioning in schizophrenia ${ }^{3-5}$.
Recently, Nicholl et al. ${ }^{6}$ suggested that a decline in the PSP scores of at least 10 points can be associated with a higher probability of relapse and Kozma et al. ${ }^{7}$ used the PSP, along with the PANSS, to analyse the risk of hospitalization and the chance of relapse, noting that patients with PSP scores below 30 had a chance 8.3 times higher than patients with PSP higher than 70 for a new hospitalization. Reviewing the literature about functional impairment in schizophrenia, Sá Junior and Souza ${ }^{8}$ indicated the ease of application in clinical practice, the speed of implementation and good reliability favorable characteristics to the use of this scale. The PSP has recently been validated in Thai ${ }^{9}$, German ${ }^{10}$, Spanish ${ }^{11}$ and Chinese ${ }^{12}$. So far there is no published data regarding the Brazilian population.

The translation and cultural adaptation of questionnaires and scales allows comparison between data obtained from different countries and cultures, but require care to avoid terminological mistakes or inadequate systematization, which can compromise the quality of collected data ${ }^{13}$.

The objective of this study was to translate and adapt the PSP scale to Portuguese and to evaluate its interrater reliability.

\section{METHODS}

\section{Translation and adaptation of the PSP}

We used the general guidelines of the method proposed by Herdman et al. ${ }^{13}$, with five steps: 1) translation of the original instrument, 2) back translation, 3) formal assessment of semantic equivalence, and 4) debriefing with a convenience sample, 5) final review by experts. The translation of the original instrument consisted of independent translations of the scale, made by two psychiatrists with experience in this area and fluent in English, able to identify the concept that covers each of the items in the original ( $M R L$ and AKPMM). The operational equivalence was taken into account, what preserves the original features, providing greater reliability and validity of the instrument. For this purpose, we kept the same number of fields, the same statements and the same options of scoring and qualification. 
Back translation consisted in translating, independently, the two Portuguese versions into English, respectively, by two different psychiatrists with experience in the area and fluent in English (PM and ARSJ). The back translators were blinded regarding the profile of professionals in the first step.

A formal assessment of semantic equivalence was made by the four professionals that completed the previous steps. We analyzed the general meanings (concepts) and referential (literal matching) of the terms and expressions used, taking into consideration not only the meaning of words, but the extent and the desired effect in the use of text in different cultures. After reviewing the comments and judgments of pairs of translations and back translations according to the amount of changes of the semantic content of each of the items examined, was made an evaluation, discussed by the translators. Then an initial version in Portuguese was prepared.

The debriefing consisted of a discussion with senior psychiatrists about their understanding of the Portuguese version of the PSP. Doubts and misunderstandings about the items of the PSP were discussed and then a final version was prepared.

\section{Interrater reliability}

The study was approved by the Research Ethical Board of the Hospital das Clínicas da FMUSP. The PSP was applied to a sample of patients diagnosed with schizophrenia by DSM-IV criteria, after written informed consent. The scale was applied to each individual at the same date by two independent investigators (AKPMM and GM), both psychiatrists, separately. None of them had access to the scores assigned by the other.

The interrater reliability between the two researchers was statistically analyzed by intraclass correlation with the SPSS package, version 14.

\section{RESULTS}

\section{Translation and adaptation}

In the assessment of semantic equivalence for some items of the PSP it was decided by one of two alternatives proposed by the translators, without altering the intended meaning. The term "manifesto" proposed in the stage of translation and back translation was replaced in the final version, by "evidente" that the translators agreed to be more appropriate to the meaning proposed. Some words had their meaning submitted for analysis and consensus of the translators for making the initial version: severe/grave; marked/acentuado; manifest/evidente; rating (noun)/pontuação; disturbing/ inconveniente (instead of disruptivo); rudeness/grosseria; whingeing/lamentações, queixumes (more popular); injuries (noun)/ferimentos. The choices were made by terms of easy understanding and analysis by professionals from different areas of health, for which the translators were not initially oriented. The final Portuguese version of the PSP is in table 1.

\section{Interrater reliability}

The PSP was applied by two independent psychiatrists to seventeen outpatients (12 males) with the diagnosis of chronic schizophrenia (according to DSM-IV criteria). Their demographic characteristics are presented in table 2 . The intraclass correlation between the two raters was 0.812 ( $95 \%$ Cl: $0.554-$ $0.928, p<0.001$ ), indicating a good interrater reliability of the PSP and that the agreement between raters does not occur by chance.

\section{DISCUSSION}

Standardizing the assessment of the socio-functional symptoms and losses determined by schizophrenia is needed to establish a uniform language among researchers and clinicians in the area. To this purpose, the translation and adaptation of diagnostic instruments and rating scales is of great importance. This should be done with care to preserve the language and different meanings inherent in each specific language guaranteeing the maintenance of meanings, contexts and cultural aspects relating to the phenomena studied by these instruments.

The final version of the PSP presented an adequate level of semantic equivalence between the original version in Portuguese and English. In addition, the steps of debriefing and analysis of the semantic equivalence, there were no difficulties related to understanding and content expressed in the translated texts and terms proposed. It showed a good interrater reliability in a small sample of patients with schizophrenia, confirming its applicability and usefulness. Even though the sample size is small and may be considered a limitation of this study, its value is similar to the interrater reliability obtained by other authors ${ }^{9-11}$.

\section{CONCLUSION}

The PSP adapted to the Portuguese used in Brazil is the initial step for its use to evaluate social functioning of patients with schizophrenia and allows comparison of Brazilian data with those found in studies conducted in other countries.

\section{CONFLICTS OF INTEREST}

All authors report no conflict of interest in relation to this study. 
Table 1. Final version of PSP in Portuguese

\title{
ESCALA PSP (Escala de Performance Social e Pessoal)
}

\author{
A pontuação é baseada em quatro áreas principais: \\ A. Atividades socialmente úteis, incluindo trabalho e estudo \\ B. Relacionamentos pessoais e sociais \\ C. Autocuidado \\ D. Comportamentos inconvenientes e agressivos
}

Os níveis de funcionamento em outras áreas devem ser considerados para ajustar a pontuação dentro do nível decimal (por exemplo entre 31 e 40 ). 0 risco de suicídio não está incluído na escala. 0 intervalo de tempo recomendado é o último mês, mas outros intervalos podem ser especificados, especialmente se o paciente está em uma crise ou acabou de superá-la.

Ocasional é definido como ocorrendo 3 ou mais vezes no período de referência, ou ocorrendo menos que 3 vezes, porém em circunstâncias e/ou com tal história prévia que 0 avaliador está convencido de que há um risco de recorrência no futuro próximo (isto é, nos próximos 6 meses). Se o comportamento agressivo está presente ocasionalmente, a pontuação pode ser diminuída de um grau, p. ex., de grave para acentuada.

De 100 a 71 pontos a pontuação significa apenas dificuldades leves, de 70 a 31 há incapacidades evidentes de graus variados e abaixo de 30 o funcionamento da pessoa é tão ruim que é necessário suporte ou supervisão intensiva.

Definições dos níveis de gravidade nas áreas A-C:

\begin{tabular}{|l|l|}
\hline Ausente & \\
\hline Leve & Dificuldades não são evidentes. Perceptíveis apenas para aqueles que têm relacionamento muito próximo com o paciente. \\
\hline Evidente & $\begin{array}{l}\text { Evidente, porém não acentuado. Dificuldades claramente percebidas por qualquer pessoa, porém sem interferência substancial na capacidade de o paciente exercer seu papel } \\
\text { em determinada área, dado seu contexto sociocultural, idade, sexo e nível educacional. }\end{array}$ \\
\hline Acentuado & $\begin{array}{l}\text { Dificuldades interferem significativamente no exercício de suas funções em determinada área; entretanto, o paciente ainda é capaz de agir sem ajuda profissional ou social, } \\
\text { apesar de inapropriadamente e/ou ocasionalmente. Caso ajudado por alguém, pode ser capaz de atingir o nível de funcionamento prévio. }\end{array}$ \\
\hline Grave & $\begin{array}{l}\text { Dificuldades que tornam o paciente incapaz de desempenhar qualquer função em determinada área, caso não ajudado por profissionais, ou que conduzam o paciente a } \\
\text { condutas destrutivas, porém sem risco de vida. }\end{array}$ \\
\hline Muito grave & Prejuízos e dificuldades cuja intensidade representa perigo de vida ao paciente. \\
\hline
\end{tabular}

Definições dos níveis de gravidade da área D:

\begin{tabular}{|l|l|}
\hline Ausente & \\
\hline Leve & Grosserias leves, insociabilidade e lamentações. \\
\hline Evidente & Falar alto demais, conversar com outros de forma excessivamente familiar ou comer de maneira socialmente inaceitável. \\
\hline Acentuado & $\begin{array}{l}\text { Insultos a pessoas em público, danificar ou destruir objetos, agir frequentemente de maneira socialmente inadequada, mas não de forma perigosa (p. ex., despir-se ou urinar } \\
\text { em público). }\end{array}$ \\
\hline Grave & Ameaças verbais frequentes ou agressões físicas frequentes, sem intenção ou possibilidade de causar ferimentos graves. \\
\hline Muito grave & Atos agressivos frequentes, visando ou com grande chance de causar ferimentos graves. \\
\hline
\end{tabular}

Assinalar o grau de incapacidade do paciente para cada área de A a D:

\begin{tabular}{|l|l|l|l|l|l|l|}
\hline & Ausente & Leve & Evidente & Acentuado & Grave & Muito grave \\
\hline A. Atividades socialmente úteis & & & & & & \\
\hline B. Relacionamentos pessoais e sociais & & & & & & \\
\hline C. Cuidados pessoais & & & & & & \\
\hline D. Comportamentos inconvenientes e agressivos & & & & & & \\
\hline
\end{tabular}

Consultar a tabela com os níveis de pontuação e estabelecer o intervalo decimal em que o paciente se encontra (p. ex., 21-30). Em seguida estabelecer, dentro do intervalo decimal, a unidade em que o paciente se encontra, para dar a pontuação final (p. ex., 24).

Níveis de pontuação:

\begin{tabular}{|c|c|}
\hline Intervalos de 10 pontos & Descrições da PSP \\
\hline $100-91$ & $\begin{array}{l}\text { Excelente funcionamento nas } 4 \text { áreas principais. Ele/ela é considerado por suas boas qualidades. Lida adequadamente com os problemas da vida, está envolvido } \\
\text { em ampla gama de interesses e atividades. }\end{array}$ \\
\hline 90-81 & Bom funcionamento nas 4 áreas principais. Presença apenas de problemas ou dificuldades comuns. \\
\hline $80-71$ & Dificuldades leves em uma ou mais áreas de A a C. \\
\hline 70-61 & Dificuldades evidentes, porém não acentuadas, em uma ou mais áreas de A a C ou dificuldades leves em D. \\
\hline $60-51$ & Dificuldades acentuadas em uma das áreas de A a C ou dificuldades evidentes em D. \\
\hline $50-41$ & Dificuldades acentuadas em duas ou mais áreas de A a C ou dificuldades graves em uma das áreas de A a C com ou sem dificuldades evidentes em D. \\
\hline $40-31$ & Graves dificuldades em uma das áreas de A a C e dificuldades acentuadas em pelo menos uma das áreas de A a C ou dificuldades acentuadas em D. \\
\hline $30-21$ & Graves dificuldades em duas das áreas de $\mathrm{A}$ a $\mathrm{C}$ ou grave dificuldade na área $\mathrm{D}$, com ou sem prejuízo nas áreas de $\mathrm{A}$ a $\mathrm{C}$. \\
\hline $20-11$ & $\begin{array}{l}\text { Graves dificuldades em todas as áreas (A a D) ou muito graves em D com ou sem prejuízo nas áreas gerais ( } \mathrm{A} \text { a C). Se o paciente reage a estímulos externos, a } \\
\text { pontuação sugerida se situa entre } 20 \text { e 16; caso contrário, a pontuação sugerida se situa entre } 15 \text { e } 11 .\end{array}$ \\
\hline $10-1$ & $\begin{array}{l}\text { Falta de autonomia no funcionamento básico com comportamentos extremos, porém sem risco de sobrevivência (pontuação de } 10 \text { a 6) ou com risco de } \\
\text { sobrevivência, p. ex., risco por desnutrição, desidratação, infecções, incapacidade evidente em reconhecer situações de perigo evidente (pontuação de } 5 \text { a 1). }\end{array}$ \\
\hline
\end{tabular}

Intervalo decimal:

Pontuação final: 
Table 2. Demographic characteristics of the sample

\begin{tabular}{lc}
\hline Gender $(\mathrm{M} / \mathrm{F})$ & $12 / 7$ \\
Age $($ mean $\pm \mathrm{sd})$ & $39.6 \pm 10.3$ years \\
Age at onset of the disease $($ mean $\pm \mathrm{sd})$ & $21.7 \pm 3.0$ years \\
Number of hospitalizations & $3.4 \pm 2.9$ \\
PSP rater AKPMM (mean $\pm \mathrm{sd}$ ) & $60.4 \pm 16.8$ \\
PSP rater GM (mean $\pm \mathrm{sd}$ ) & $59.1 \pm 19.0$ \\
\hline
\end{tabular}

\section{REFERENCES}

1. Tandon R, Nasrallah HA, Keshavan MS. Schizophrenia, "just the facts" 4. Clinical features and conceptualization. Schizophr Res. 2009;110(1-3):1-23.

2. Morosini PL, Magliano L, Brambilla L, Ugolini S, Pioli R. Development, reliability and acceptability of a new version of the DSM-IV Social and Occupational Functioning Assessment Scale (SOFAS) to assess routine social functioning. Acta Psychiatr Scand. 2000;101(4):323-9.

3. Patrick DL, Burns T, Morosini P, Rothman M, Gagnon DD, Wild D, et al. Reliability, validity and ability to detect change of the clinician-rated Personal and Social Performance scale in patients with acute symptoms of schizophrenia. Curr Med Res Opin. 2009;25(2):325-38.

4. Nasrallah H, Morosini P, Gagnon DD. Psychiatry, reliability, validity and ability to detect change of the Personal and Social Performance scale in patients with stable schizophrenia. Psychiatry Res. 2008;161(2):213-24.
5. Kawata AK, Revicki DA. Psychometric properties of the Personal and Social Performance scale (PSP) among individuals with schizophrenia living in the community. Qual Life Res. 2008;17(10):1247-56. Epub 2008 0ct 15.

6. Nicholl D, Nasrallah H, Nuamah I, Akhras K, Gagnon DD, Gopal S. Personal and social functioning in schizophrenia: defining a clinically meaningful measure of maintenance in relapse prevention. Curr Med Res 0pin. 2010;26(6):1471-84.

7. Kozma CM, Dirani RG, Canuso CM, Mao L. Predicting hospital admission and discharge with symptom or function scores in patients with schizophrenia: pooled analysis of a clinical trial extension. Ann Gen Psychiatry. 2010;9:24.

8. Sá Júnior AR, Souza MC. Avaliação do comprometimento funcional na esquizofrenia. Rev Psiq Clín. 2007;34(2 Suppl):164-8.

9. Srisurapanont M, Arunpongpaisal S, Chuntaruchikapong S, Silpakit C, Khuangsirikul V, Karnjanathanalers $\mathrm{N}$, et al. Cross-cultural validation and inter-rater reliability of the Personal and Social Performance scale, Thai version. Med Assoc Thai. 2008;91(10):1603-8.

10. Juckel G, Schaub D, Fuchs N, Naumann U, Uhl I, Witthaus H, et al. Validation of the Personal and Social Performance (PSP) Scale in a German sample of acutely ill patients with schizophrenia. Schizophr Res. 2008;104(1-3):287-93.

11. Apiquian R, Elena Ulloa R, Herrera-Estrella M, Moreno-Gómez A, Erosa S, Contreras V, et al. Validity of the Spanish version of the Personal and Social Performance scale in schizophrenia. Schizophr Res. 2009;112(1-3):181-6.

12. Tianmei S, Liang S, Yun'ai S, Chenghua T, Jun Y, Jia C, et al. The Chinese version of the Personal and Social Performance Scale (PSP): validity and reliability. Psychiatry Res. 2011:185(1-2):275-9

13. Herdman M, Fox-Rushby J, Badia X. A model of equivalence in the cultural adaptation of HRQoL instruments: the universalist approach. Qual Life Res. 1998;7(4):323-35. 